\title{
Vittorio Caporrella, Il modello di famiglia borghese nell'Ottocento
}

\section{Marco Stupazzoni}

\section{(2) OpenEdition}

1 Journals

\section{Edizione digitale}

URL: http://journals.openedition.org/studifrancesi/6333

DOI: 10.4000/studifrancesi.6333

ISSN: 2421-5856

\section{Editore}

Rosenberg \& Sellier

\section{Edizione cartacea}

Data di pubblicazione: 1 novembre 2010

Paginazione: 564

ISSN: 0039-2944

\section{Notizia bibliografica digitale}

Marco Stupazzoni, «Vittorio Caporrella, II modello di famiglia borghese nell'Ottocento», Studi Francesi [Online], 162 (LIV | III) | 2010, online dal 30 novembre 2015, consultato il 07 janvier 2021. URL: http:// journals.openedition.org/studifrancesi/6333 ; DOI: https://doi.org/10.4000/studifrancesi.6333

Questo documento è stato generato automaticamente il 7 janvier 2021.

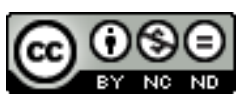

Studi Francesi è distribuita con Licenza Creative Commons Attribuzione - Non commerciale - Non opere derivate 4.0 Internazionale. 


\title{
Vittorio Caporrella, Il modello di famiglia borghese nell'Ottocento
}

\author{
Marco Stupazzoni
}

\section{NOTIZIA}

VITTORIO CAPORRELLA, Il modello di famiglia borghese nell'Ottocento, in La Famiglia.

Un'istituzione che cambia, Bologna, Archetipolibri, 2008, pp. 93-109.

1 Seguendo un approccio metodologico prettamente diacronico e mantenendo comunque viva l'esigenza di coniugare la dimensione cronologica con le prospettive dei diversi approcci storiografici e disciplinari, l'autore affronta in questa sezione la questione del rapporto ambivalente tra famiglia e Stato-nazione nell'Ottocento. Il modello di famiglia borghese descritto dall'A. segna la nascita di un ideale di famiglia inteso come «centro affettivo, caratterizzato dall'intimità, dall'ideale dell'amore coniugale, dalla separazione fra ambito politico e sfera privata» (p.93). Da questo punto di vista, la produzione romanzesca del XIX secolo costituisce una delle fonti privilegiate per studiare e comprendere il modello sentimentale ottocentesco: le opere di Balzac (di cui vengono riportati due brani tratti da Le Père Goriot e da La Cousine Bette) e di Flaubert, ad esempio, intendono denunciare, penetrando con occhio vigile e spietato gli spazi angusti e nascosti delle mura domestiche, «le ipocrisie della morale, smascherare la pratica dell'adulterio extraconiugale, descrivere la condizione di inferiorità a cui era costretta la donna, il tutto in un quadro di rapporti che richiedeva la subordinazione delle aspirazioni e dei sentimenti individuali alle strategie familiari» (ibid.). 